\title{
RANCANG BANGUN SISTEM MONITORING KINERJA PANEL SURYA BERBASIS MIKROKONTROLLER ATMEGA 328
}

\author{
Dewa Gede Dede Pramana ${ }^{1}$, I Wayan Arta Wijaya ${ }^{2}$, I Made Arsa Suyadnya ${ }^{3}$ \\ ${ }^{123}$ Program Studi Teknik Elektro, Fakultas Teknik, Universitas Udayana \\ Email: dewa261@gmail,com ${ }^{1}$, artawijaya@ee.unud.ac.id ${ }^{2}$, ${\text { arsa.suyadnya@unud.ac.id }{ }^{3}}$
}

\begin{abstract}
ABSTRAK
Penelitian ini bertujuan untuk mengembangkan sebuah sistem yang mampu melakukan monitoring kinerja panel surya. Rancang bangun ini berbasis mikrokontroller atmega 328. Dalam pembuatan sistem ini dibagi menjadi dua bagian yaitu pertama, perancangan perangkat keras (hardware) yang terdiri dari perancangan perangkat elektronika. Kedua, perancangan perangkat lunak (software). Pemrograman sistem monitoring dan pencatatan data menggunakan software Microsoft visual basic dan arduino IDE. Hasil pengujian menggunakan beban lampu light emitting diode(LED) $12 \mathrm{v}$, sistem monitoring telah dapat menginformasikan bila pada panel surya terjadi gangguan penurunan tegangan dengan adanya indikator pada sisi-sisi panel, apabila tegangan berada dibawah batas minimum $8 \mathrm{v}$, maka pada sisi panel merah menyala sebagai indikator kurang baik, namun sebaliknya akan menyala hijau jika tegangan di atas batas tegangan minimum yaitu $8 \mathrm{v}$ dan berstatus baik. Hasil pengujian software sudah berhasil menunjukkan hasil yang diharapkan pada saat pengujian menggunakan metode black box testing.
\end{abstract}

Kata Kunci : Panel Surya, ArduinolDE, Microsoft visual basic.

\section{ABSTRACT}

This research aims to develop a system capable of monitoring the performance of solar panels. This design is based on microcontroller atmega 328. In making this system is divided into two parts, namely, the design of hardware (hardware) which consists of the design of electronic devices. Second, the design of software (software). Programming of monitoring and recording system using Microsoft visual basic and arduino IDE software. Testing results using $12 \mathrm{v}$ light emitting diode (LED), monitoring system has been able to inform if the solar panel there is a voltage drop in the presence of an indicator on the sides of the panel, if the voltage is below the minimum $8 v$, then on the red panel panel lights up the indicator is not good, otherwise it will turn green if the voltage above the minimum voltage limit is $8 \mathrm{v}$ and the status is good. The results of software testing have been successful showing the expected results at the time of testing using black box testing method.

Keywords : Solar Panel, ArduinolDE, Microsoft visual basic.

\section{PENDAHULUAN}

Pada daerah khatulistiwa matahari bersinar selama 12 jam setiap harinya, sepanjang tahun, dengan intensitas yang tinggi $4,8 \mathrm{kWH} / \mathrm{m}^{2} /$ hari. Kondisi ini berbeda dibandingkan dengan daerah-daerah seperti Jerman, Jepang, dan Amerika Serikat yang telah banyak memanfaatkan sumber energy dari cahaya matahari.

Pengembangan teknologi solar cell di seluruh dunia terus dilakukan. Solar cell yang dikembangkan itu juga memanfaatkan sistem kontrol/monitoring. Sistem monitoring didefinisikan sebagai siklus kegiatan yang mencakup pengumpulan, peninjauan ulang, pelaporan, dan tindakan atas informasi suatu proses yang sedang diimplementasikan. Monitoring dapat memberikan informasi keberlangsungan proses untuk menetapkan langkah menuju ke arah perbaikan yang berkesinambungan [1].

Penelitian mengenai sistem monitoring terhadap panel surya telah dilakukan sebelumnya oleh [2]. Penelitian ini membahas mengenai perancangan sistem monitoring output dan pencatatan data pada PLTS 
berbasis mikorkontroller Arduino. Penelitian yang dilakukan hanya menggunakan satu panel surya, dan hasilnya berupa pencatatan data tegangan, arus, dan daya pada panel surya dan masing-masing data disimpan langsung pada microsd setiap 15 menit. Penelitian [2] belum menggunakan antarmuka dengan software, baru sebatas dengan perangkat arduino saja dan hanya satu panel surya. Penelitian [3] membahas akuisisi solar cell dengan menggunakan Program Labview. Penelitian ini menghasilkan sebuah program aplikasi berbasis komputer. Data yang telah diinputkan ke komputer selanjutnya akan diproses dengan menggunakan program LabView, sehingga data hasil akuisisi tersebut dapat ditampilkan pada sebuah komputer sebagai monitoring. Penelitian [4] membahas pembuatan sistem monitoring optimasi energi cahaya matahari menggunakan sensor arus pada antarmuka personal computer, penelitian ini menghasilkan motorservo DC untuk mengendalikan gerak panel sel surya, pengontrol waktu setiap derajat motor servo DC menggerakkan panel sel surya, pengontrol waktu pengukuran dan pensaklaran panel diam ke panel bergerak, dan mengirim data secara serial ke personal computer menggunakan mikrokontroler AVRATMega8535.

Dari paparan penelitian-penelitian sebelumnya, maka pada penelitian ini akan mengembangkan penelitian [1] yaitu merancang sistem yang dapat memonitoring kinerja pada panel surya berbasis mikrokontroller dengan komputerisasi. Penelitian ini menggunakan tiga panel surya, tiga sensor arus, tiga sensor tegangan, Data arus dan tegangan yang didapat dari panel surya tersebut nanti akan diproses di arduino sebelum ditampilkan pada software di laptop. Dengan menggunakan perangkat komputer diharapkan sistem ini mampu bekerja dengan respon waktu yang lebih cepat dan mampu memonitor setiap saat agar operator yang mengontrol nantinya bisa melakukan tindakan berdasarkan prosedur yang telah ditetapkan nantinya.

\section{KAJIAN PUSTAKA}

\subsection{Sistem Monitoring}

Monitoring adalah siklus kegiatan yang mencakup pengumpulan, peninjauan ulang, pelaporan, dan tindakan atas informasi suatu proses yang sedang diimplementasikan.
Umumnya, monitoring digunakan dalam checking antara kinerja dan target yang telah ditentukan. Monitoring ditinjau dari hubungan terhadap manajemen kinerja adalah proses terintegrasi untuk memastikan bahwa proses berjalan sesuai rencana (on the track) [3].

\subsection{Sensor Arus ACS712}

Sensor arus ACS712 menggunakan metode Hall Effect Sensor. Hall Effect Sensor merupakan sensor yang digunakan untuk mendeteksi medan magnet. Sensor ini terdiri dari sebuah lapisan silikon yang berfungsi untuk mengalirkan arus listrik. [4].

\subsection{Sensor Tegangan}

Sensor tegangan adalah salah satu jenis sensor yang berfungsi untuk mengukur tegangan listrik. Sensor ini didasarkan pada prinsip tekanan resistensi dan dapat membuat tegangan input dari terminal mengurangi 5 kali dari tegangan asli [5].

\subsection{Arduino Uno}

Arduino Uno adalah board berbasis mikrokontroler pada ATmega328. Board ini memiliki 14 pin digital input/output, Enam pin dapat digunakan sebagai output PWM, 6 input analog, $16 \mathrm{MHz}$ osilator kristal, jack listrik tombol reset. Koneksinya hanya terhubung ke komputer dengan kabel USB atau sumber tegangan bisa didapat dari adaptor AC-DC atau baterai untuk menggunakannya [6].

\subsection{Sel Surya}

Sel surya adalah suatu alat semikonduktor yang menkonversi cahaya ke dalam listrik. Konversi ini disebut efek photovoltaic, dengan kata lain efek photovoltaic adalah fenomena dimana suatu sel photovoltaic dapat menyerap energi cahaya dan mengubahnya menjadi energi listrik. Efek photovoltaic adalah suatu fenomena munculnya voltase listrik akibat kontak dua elektroda yang menghubungkan dengan sistem padatan atau cairan saat diexpose di bawah energi cahaya [7].

\subsection{Microsoft Visual Basic}

Visual Basic adalah salah suatu development tools untuk membangun aplikasi dalam lingkungan Windows. Dalam pengembangan aplikasi, Visual Basic 
menggunakan pendekatan Visual untuk merancang user interface dalam bentuk form, sedangkan untuk kodingnya menggunakan bahasa Basic yang cenderung mudah dipelajari [8].

\section{DESAIN SISTEM}

\subsection{Langkah-langkah Penelitian}

Adapun langkah-langkah penelitian yang akan dilakukan adalah sebagai berikut:

1. Pendefinisian dari software yang akan dibuat untuk menambah pemahaman mengenai lingkup topik yang akan dikerjakan.

2. Pengumpulan data yang berhubungan dengan rancang bangun sistem monitoring kinerja panel surya berbasis mikrokontroller atmega 328.

3. Perancangan skema dan layout rangkaian elektronik menggunakan Microsoft Visio 2007.

4. Perancangan algoritma komunikasi antara Panel Surya dengan GCS dengan membuat flowchart menggunakan Microsoft Visio 2007.

5. Pembuatan GUI dari GCS(Ground Control Software) menggunakan Microsoft Visual Studio 2010.

6. Pengujian nilai minimum dari sensor tegangan.

7. Pengujian komunikasi antara Panel Surya dengan komputer.

8. Pengujian software pada Microsoft visual studio 2010.

9. Membahas data hasil dari pengujian.

10. Pengambilan kesimpulan.

Pengoperasian data logger yang telah terhubung dengan software memiliki 2 proses yakni 1) proses pengiriman data dari data logger menuju software, 2) penyimpanan, penghapusan dan penampilan data pengukuran pada database software yang telah dirancang.

\subsection{Gambaran Umum Sistem}

Penelitian ini terdiri dari dua bagian yaitu software dan panel surya yang ditunjukkan pada Gambar 1. Pada Ground Control Software (GCS) operator login ke sistem dan software memulai pengambilan data arus dan tegangan dari sensor yang terpasang pada panel surya, kemudian data arus dan tegangan dipilah sesuai dengan nomor panel, Penelitian ini menggunakan nilai minimum tegangan sebagai acuan untuk menentukan status panel. Data tegangan yang terukur akan dibandingkan dengan nilai tegangan minimum, Apabila nilai tegangan kurang dari nilai minimum maka sisi panel akan berwarna merah dan berstatus kurang baik, Sebaliknya akan menyala hijau jika tegangan lebih dari nilai minimum dan berstatus baik.

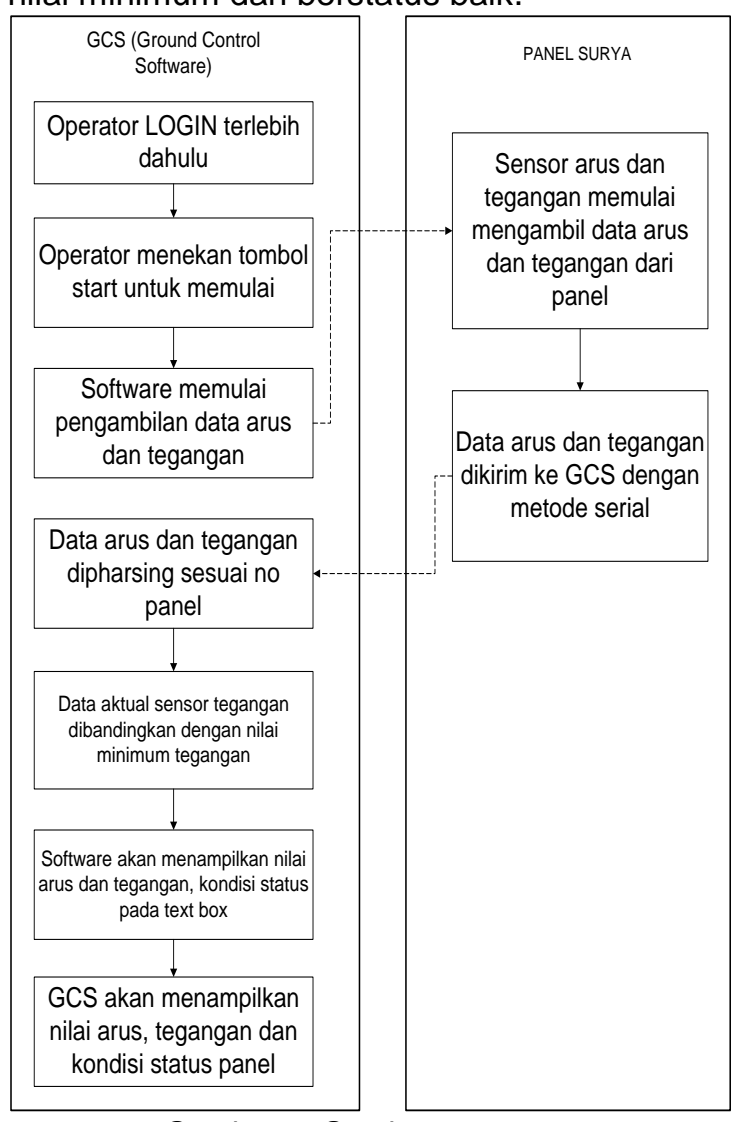

Gambar 1. Gambaran umum

\subsection{Diagram Alir GCS(Ground Control Software)}

Diagram Gambar 2 menggunakan software Arduino IDE, Pada diagram GCS awalnya operator menekan tombol start dilanjutkan dengan memasukkan inisialisasi tipe data nilai karakteristik tegangan minimum. Langkah berikutnya mengirimkan ke database, di panel surya akan menerima data nilai aktual dari sensor tegangan yang dipasang pada panel. Nilai data aktual tersebut akan dipilah. Selanjutnya pada GCS akan membandingkan nilai karakteristik tegangan minimum dan nilai tegangan aktual yang diperoleh dari sensor. Apabila data nilai aktual kurang dari data nilai minimum, maka sisi panel akan menyala merah dan berstatus kurang baik. Jika tidak, maka sisi panel akan 
menyala hijau dan berstatus baik. Selanjutnya kembali ke proses awal.

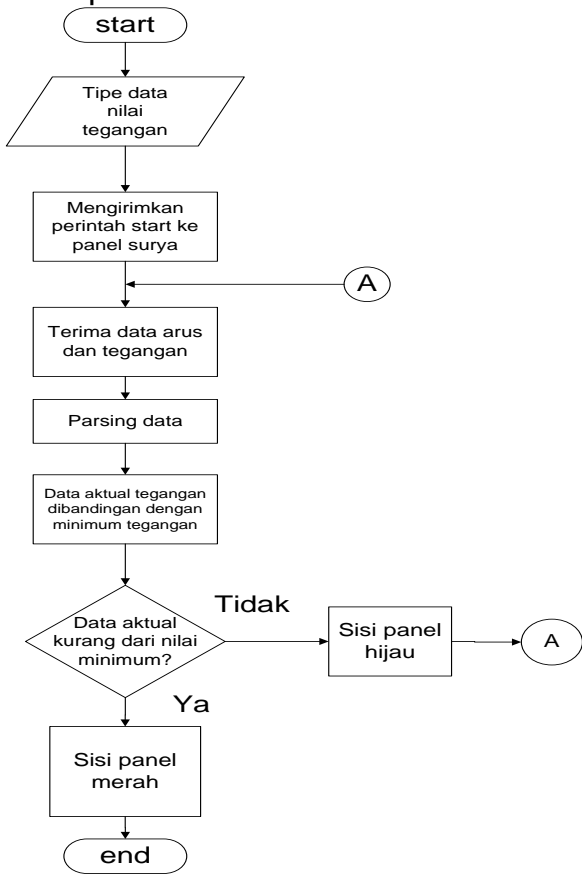

Gambar 2. Diagram alir GCS menggunakan software Arduino IDE

\subsection{Diagram Alir Panel Surya}

Diagram alir panel surya ditunjukkan pada Gambar 3. Diagram alir panel surya dimulai dari inisialisasi data yang akan digunakan, Apabila perintah start sudah dimulai, maka sensor arus dan sensor tegangan mulai memberikan data nilai aktual. Data aktual ini akan dikirimkan langsung ke Ground Control Software(GCS) untuk dipilah dan dibandingkan dengan nilai tegangan minimum, selanjutnya kembali ke proses awal.

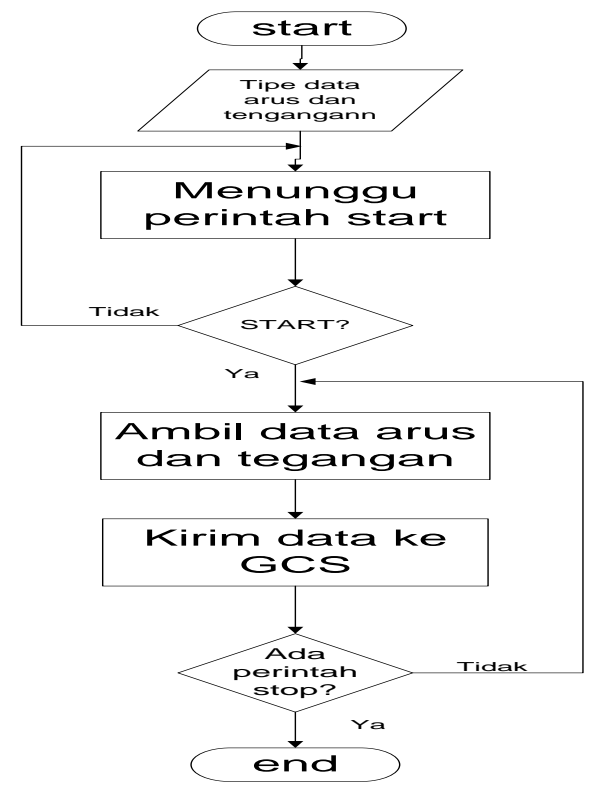

Gambar 3. Diagram alir panel surya

\subsection{Perancangan Database}

Tabel dalam database yang dirancang terdiri dari dua tabel yaitu Tabel User dan Tabel Panel. Tampilan perancangan database dapat dilihat pada Gambar 4.
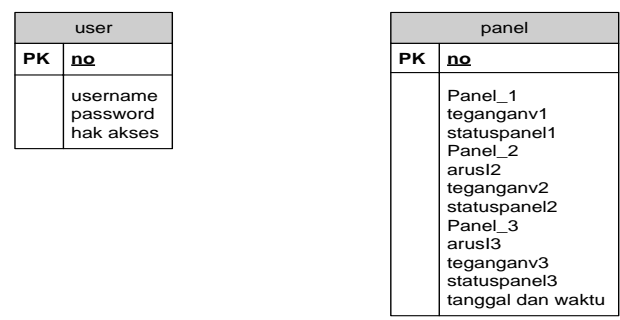

Gambar 4. Perancangan tabel database

4. HASIL dan PEMBAHASAN

4.1 Realisasi Hasil Perancangan

Perangkat Keras dan Perangkat Lunak

Realisasi perancangan perangkat keras Tampak atas dan tampak samping tanpa panel surya dapat dilihat pada Gambar 5 . Realisasi perangkat lunak pada Gambar 6.
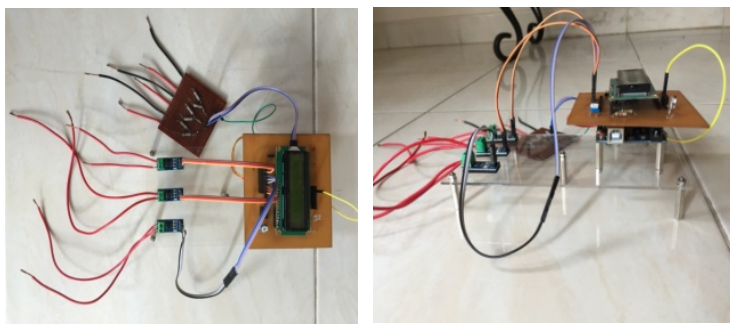
Gambar 5. Realisasi perangkat keras (tampak atas dan samping)

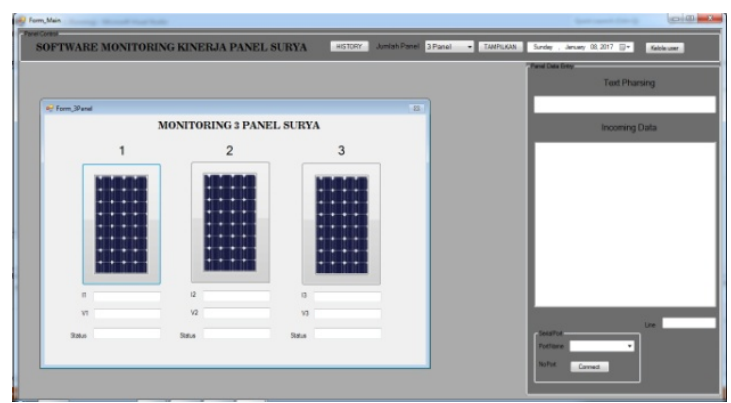

Gambar 6. Realisasi hasil perancangan perangkat lunak

\subsection{Pengujian Karakteristik Arus dan Tegangan Panel Surya}

Pengujian tegangan dan arus pada panel surya, awalnya dilakukan pengukuran tegangan pada panel surya tanpa menggunakan beban. Hasil pengukuran adalah 20,7 volt, Sedangkan karakteristik tegangan pada panel adalah 20,6 volt. Pengukuran arus dilakukan dengan cara member beban lampu led 12 volt. Hasil pengukuran adalah 0,40 ampere, Sedangkan karakteristik arus pada panel adalah 0,65 ampere. Berikut Gambar 7 yang menunjukkan saat melakukan pengukuran panel surya menggunakan Avometer untuk mengetahui besar tegangan dan arus panel surya.

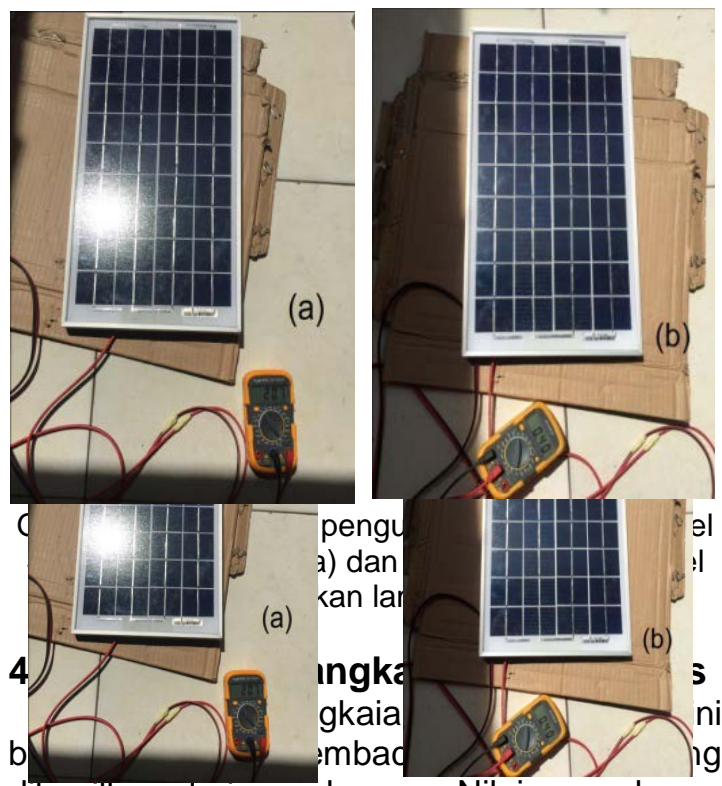

dihasilkan darı panel surya. Nilai pengukuran dikonversi dengan mikrokontroller arduino untuk mendapatkan hasil yang diinginkan.
Pengujian sensor arus menggunakan mikrokontroller arduino untuk memproses pembacaan nilai analog dari hasil pengukuran pada objek yang diukur.

Tabel 1. Hasil pengujian sensor arus

\begin{tabular}{|c|c|c|c|c|}
\hline no & sumber & beban & \multicolumn{2}{|c|}{ Hasil pengukuran } \\
\cline { 4 - 5 } & & & $\begin{array}{c}\text { ampermeter } \\
(\mathrm{A})\end{array}$ & $\begin{array}{c}\text { Sensor } \\
\text { Arus(A) }\end{array}$ \\
\hline 1 & 5 volt & $10 \mathrm{ohm}$ & 0,41 & 0,42 \\
\hline 2 & 7,4 volt & $10 \mathrm{ohm}$ & 0,87 & 0,67 \\
\hline 3 & 12 volt & $10 \mathrm{ohm}$ & 1,15 & 1,18 \\
\hline 4 & 20 volt & $10 \mathrm{ohm}$ & 1,76 & 1,79 \\
\hline
\end{tabular}

Berikut merupakan hasil perhitungan presentase perbedaan nilai amperemeter dengan sensor arus.

1. Perbedaan $=\left|\frac{0,42-0,41}{0,41}\right| \times 100 \%=2,4 \%$

2. Perbedaan $=\left|\frac{0,67-0,87}{0,87}\right| \times 100 \%=1,5 \%$

3. Perbedaan $=\left|\frac{1,18-1,15}{1,15}\right| \times 100 \%=2,6 \%$

4. Perbedaan $=\left|\frac{1,79-1,76}{1,76}\right| \times 100 \%=1,7 \%$

Dari perhitungan persentase tersebut didapatkan hasilkan persentase perbedaan nilai arus dengan amperemeter sebesar 2,6\% dari maksimun nilai toleransi pengukuran amperemeter $3.2 \%$. Sehingga hasil pengujian masih dalam toleransi pembacaan ampermeter.

\subsection{Pengujian Sensor Tegangan}

Pengujian rangkaian sensor tegangan ini bertujuan untuk membaca output tegangan yang dihasilkan dari panel surya, Nilai pengukuran dikonversi dan sebagai kalibrasi di mikrokontroller arduino sehingga menunjukkan hasil yang diinginkan. Pengujian sensor tegangan menggunakan mikrokontroller arduino untuk memproses pembacaan nilai analog dari hasil pengukuran pada objek yang diukur.

Tabel 2. Hasil pengujian sensor tegangan

\begin{tabular}{|c|c|c|c|}
\hline \multirow{2}{*}{ no } & Sumber & \multicolumn{2}{|c|}{ Hasil Pengukuran } \\
\cline { 3 - 4 } & & $\begin{array}{c}\text { Voltmeter( } \\
\text { v) }\end{array}$ & $\begin{array}{c}\text { Sensor } \\
\text { tegangan(v) }\end{array}$ \\
\hline 1 & Regulator 5 v & 4,96 & 4,98 \\
\hline 2 & Baterai 7,4 v & 7,22 & 7,36 \\
\hline 3 & Led 12 v & 11,55 & 11,75 \\
\hline 4 & Panel surya 20 v & 19,46 & 19,79 \\
\hline
\end{tabular}


Berikut merupakan hasil perhitungan presentase perbedaan nilai voltmeter dengan sensor tegangan.

1. Perbedaan $=\left|\frac{4,95-4,93}{4,93}\right| \times 100 \%=0,42 \%$

2. Perbedaan $=\left|\frac{7,36-7,22}{7,22}\right| \times 100 \%=0,19 \%$

3. Perbedaan $=\left|\frac{11,75-11,53}{11,53}\right| \times 100 \%=1,9 \%$

4. Perbedaan $=\left|\frac{19,79-19,46}{19,46}\right| \times 100 \%=1,06 \%$

Dari perhitungan persentase tersebut didapatkan hasilkan persentase perbedaan nilai tegangan dengan voltmeter sebesar $1.9 \%$ dari maksimum nilai toleransi pengukuran voltmeter sebesar $2.5 \%$.

\subsection{Pengujian Login}

Pengujian form login ini bertujuan agar tidak sembarang orang bisa masuk ke dalam sistem. User dengan hak akses sebagai admin dapat melakukan management data aplikasi, sedangkan user dengan hak akses sebagai staff dan lainnya hanya dapat melihat sistem monitoring. User diharuskan untuk memasukan username dan password seperti terlihat pada Gambar 8.

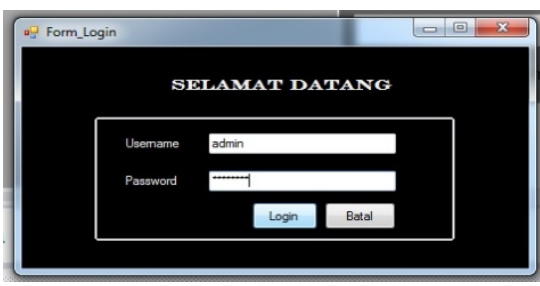

Gambar 8. Pengujian Form Login

\subsection{Pengujian Pengeloalaan User}

Pengujian user bertujuan untuk mengatur user/operator yang menggunakan software ini. Gambar 9 merupakan halaman kelola user yang mempunyai fitur antara lain admin dapat menambah user baru, mengubah username dan password user, serta menghapus user.

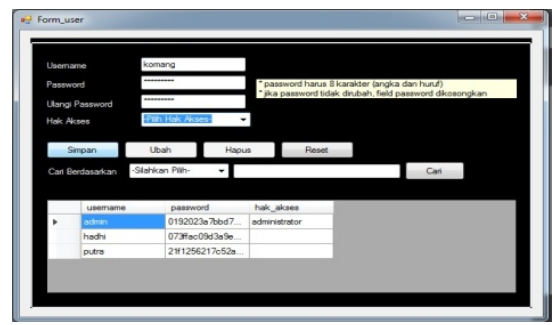

Gambar 9. Pengujian Pengelolaan User

\subsection{Pengujian Nilai Minimum Tegangan Panel Surya}

Pengujian nilai minimum tegangan panel bertujuan untuk mengetahui jika panel terjadi penurunan tegangan dari karakteristik panel sehingga pada sisi panel akan berwarna merah dan berstatus kurang baik. Sebaliknya, jika tegangan lebih dari karakteristik panel yang sebelumnya diukur maka akan berwarna hijau dan berstatus baik. Gambar 10 merupakan pengujian nilai tegangan minimum pada saat menggunakan beban lampu led $12 \mathrm{v}$ yaitu $8,1 \mathrm{v}$. Pengujian ini sebagai acuan jika nilai tegangan kurang dari nilai minimum maka panel akan berwarna merah dan berstatus kurang baik.

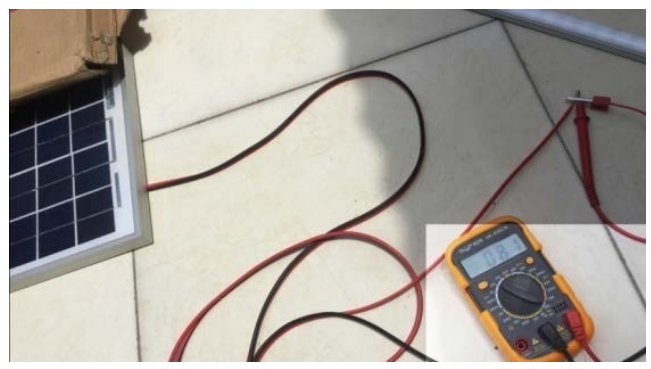

Gambar 10. Hasil pengujian minimum tegangan

\subsection{Pengujian Kondisi Panel}

Kondisi Panel diujikan dengan cara menutup dengan benda tidak tembus cahaya pada masing-masing panel. Ketika tegangan kurang dari tegangan minimum, maka tampilan monitoring masing-masing panel akan berubah menjadi merah dan berstatus kurang baik. Gambar 11, menunjukkan nilai tegangan pada panel 3 yaitu $0,15 \mathrm{v}$ kurang dari nilai tegangan minimum yaitu $8 \mathrm{v}$, maka pada sisi panel 3 berwarna merah dan berstatus kurang baik.

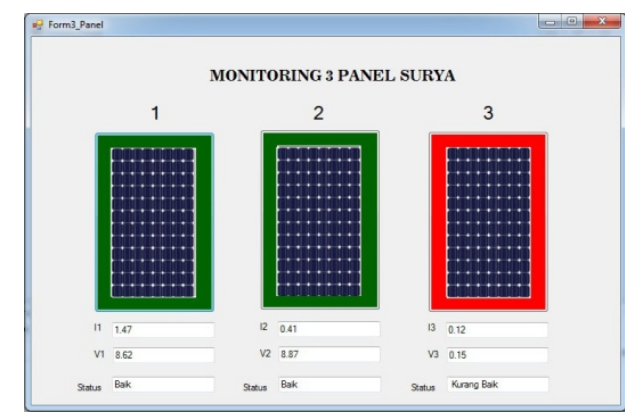

Gambar 11. Tampilan software monitoring pada saat panel 3 ditutup 
Gambar 12, menunjukkan nilai tegangan pada panel 2 dan 3 yaitu $0,57 \mathrm{v}$ dan $1,02 \mathrm{v}$ kurang dari nilai tegangan minimum yaitu $8 \mathrm{v}$ maka pada sisi panel 2 dan 3 berwarna merah dan berstatus kurang baik

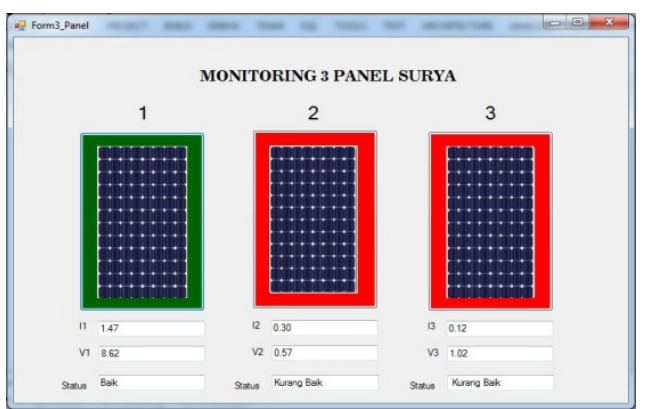

Gambar 12. Tampilan software monitoring pada saat panel 2 dan 3 ditutup

Gambar 13, menunjukkan nilai tegangan pada panel 1,2 , dan 3 yaitu $0,68 \mathrm{v}, 0,57 \mathrm{v}$, $0,49 \mathrm{v}$ kurang dari nilai tegangan minimum yaitu $8 \mathrm{v}$, maka pada sisi panel 1, 2, dan 3 berwarna merah dan berstatus kurang baik.

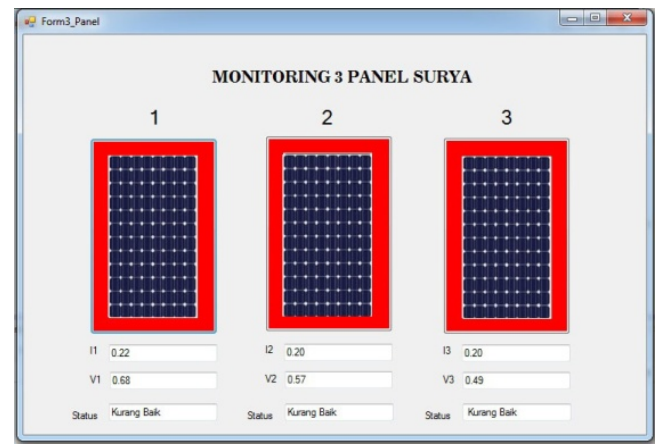

Gambar 13. Tampilan software monitoring pada saat semua panel ditutup

\subsection{Pengujian Data pada History Database}

Pengujian ini memiliki 2 fungsi, Pertama, pengambilan dan penyimpanan data arus, tegangan, dan status. Fungsi kedua, untuk menampilkan data yang sudah tersimpan pada database.
Tabel 3. Tampilan data history database yang te

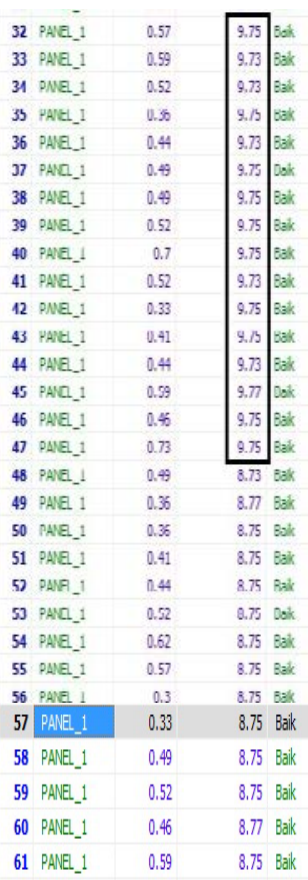

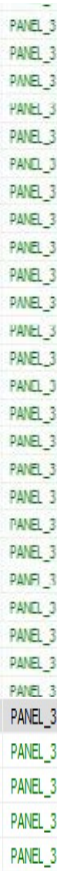

Tampilan history database yang sudah tersimpan ditunjukkan pada Tabel 3. Hasil monitoring dan pencatatan data pada tanggal 08 Februari 2017 mulai pukul 9.00 pagi sampai 17.00 pada Tabel. 3, nilai tegangan terbesar pada pukul 11.45 sampai pukul 13.10 wita yaitu sebesar $9,75 \mathrm{v}$.

\section{KESIMPULAN}

Berdasarkan hasil dari pengujian dan pembahasan yang telah dilakukan, Sistem monitoring kinerja panel surya berbasis mikrokontroller Atmega 328 telah berhasil diimplementasikan. Berdasarkan hasil pengujian menggunakan beban lampu led $12 \mathrm{v}$, sistem monitoring telah dapat menginformasikan bila pada panel surya terjadi gangguan penurunan tegangan dengan adanya indikator pada sisi-sisi panel, bila berkedip merah maka tegangan kurang dari batas tegangan minimum yaitu $8,0 \mathrm{v}$ dan akan berstatus kurang baik, namun sebaliknya akan berkedip hijau jika tegangan lebih dari batas tegangan minimum yaitu $8,0 \mathrm{v}$ dan berstatus baik. Pengujian software sudah berhasil menunjukkan hasil yang diharapkan menggunakan metode black box test.. Untuk 
pengembangan sistem ini dapat ditambahkan perangkat wireless untuk komunikasi jarak jauh dan panel surya yang lebih banyak.

\section{DAFTAR PUSTAKA}

[1] Putro, Muhamad Revo D. 2014. Rancang Bangun Sistem Informasi Monitoring Antrian Pada Koperasi Setia Bhakti Wanita Berbasis Web(Skripsi). Surabaya: STIKOM Surabaya.

[2] Winata, P. P. T . 2015. Rancang Bangun Sistem Monitoring Output dan Pencatatan Data pada PLTS Berbasis Mikrokontroller Arduino(Skripsi). Bali: Universitas Udayana.

[3] Ridho, Ahmad Z. 2010. Akuisi Solar Cell dengan menggunakan program Labview(Skripsi). Bandung: UNIKOM.

[4] Hutauruk, Oki P. 1987. Studi Optimasi Untuk Lokasi Gardu Induk(Skripsi). Medan: Universitas Sumatera Utara.

[5] Nalwan, A. Teknik Rancang Bangun Robot. Yogyakarta : Andi offset.2012.

[6] Kadir, Abdul. Zero to a pro, Arduino. Yogyakarta:CV. ANDI OFFSET. 2015.

[7] Arduino ${ }^{\mathrm{TM}}$. (t.t.). ArduinoUno. http://www.arduino /download files/manual. Pdf, diakses tanggal 14 Desember 2017.

[8] Mintorogo, Danny santoso, Strategi Aplikasi sel surya pada perumahan dan bangunan konversial. Jurnal Universitas Kristen Petra, Vol.28 No.2.

[9] Agussalim. "Sistem Informasi Penjualan Obat Pada Apotik Rumah Sakit U'Budiyah Indonesia Menggunakan Visual Basic 6.0" STMIK U'Budiyah Indonesia. 2012.

[10] Shocket, Abe. Smart Charging Systems for Plug-in Electric Vehicles. World Electric Vehicle Journal Vol. 5, 2012.

[11] I.B.A.Swamardika,I.N.Budiastra,I.N. Setiawan,M.Y. Hendrayanto, dan I.P.A.M.Pratama. Rancang Bangun Robot 6WD sebagai Alat Pendektesi Kebocoran Gas Berbasis Komunikasi Wireless XBee-Pro Seriel $160 \mathrm{~mW}$. Jurnal Teknik elektro universitas udayana Vol.14 No.1,2015. 